\title{
Association between the morphological and productive characteristics in the selection of elephant grass clones $^{1}$
}

\author{
Márcio Vieira da Cunha ${ }^{2}$, Mario de Andrade Lira ${ }^{2}$, Mércia Virginia Ferreira dos Santos ${ }^{3}$, Erinaldo \\ Viana de Freitas ${ }^{2}$, José Carlos Batista Dubeux Junior ${ }^{3}$, Alexandre Carneiro Leão de Mello ${ }^{3}$, Kalina \\ Gerciane Rodovalho Martins ${ }^{3}$
}

\footnotetext{
1 Trabalho financiado pelo Banco do Nordeste.

2 Instituto Agronômico de Pernambuco (IPA).

${ }^{3}$ Universidade Federal Rural de Pernambuco (UFRPE).
}

ABSTRACT - The objectives in this work were to study the association between the morphological and productive characteristics in Pennisetum sp. clones, and to identify the morphological characteristics responsible for the productivity in Pennisetum cp. clones. The canonical correlations were evaluated and the path analysis was made from the simple genotypic correlation matrix between the morphological and productive characteristics of eight Pennisetum sp. clones (Taiwan A-146 2.37, Taiwan A-146 2.27, Taiwan-146 2.114, Merker México MX 6.31, Mott, HV-241, Elefante B and IRI-381). The canonical correlations were significant at $1 \%$ probability by the Chi-square test. The first pair of canonic factors, with correlation of 0.9999, related the plants with the highest dry matter content to plants with lower leaf area indexes, light perception and leaf angle. The second pair of canonic factors, with correlation of 0.9999, related the plants with the highest dry matter production to the plants with higher basal tiller density, height, and low green leaf number per tiller. The results of the path analysis indicated that the light interception is determinant in dry matter content expression of Pennisetum sp. clones, while the basal tiller density and plant height are responsible for dry matter production in these clones.

Key Words: canonic correlation, dry matter content, dry matter production, millet, path analysis, Pennisetum sp.

\section{Associação entre características morfológicas e produtivas na seleção de clones de capim-elefante}

RESUMO - Os objetivos neste trabalho foram estudar a associação entre características morfológicas e produtivas em clones de Pennisetum sp. e identificar as características morfológicas responsáveis pela produtividade em clones de Pennisetum sp. Foram avaliadas as correlações canônicas e feita análise de trilha a partir da matriz de correlações genotípicas simples entre características morfológicas e produtivas de oito clones de Pennisetum sp. (Taiwan A-146 2.37, Taiwan A-146 2.27, Taiwan146 2.114, Merker México MX 6.31, Mott, HV-241, Elefante B e IRI-381). As correlações canônicas foram significativas a $1 \%$ de probabilidade pelo teste do qui-quadrado. O primeiro par de fatores canônicos, com correlação de 0,9999, associou plantas com maior teor de matéria seca a plantas com menores índices de área foliar, interceptação luminosa e ângulo foliar. O segundo par de fatores canônicos, com correlação de 0,9999, associou plantas com maior produção de matéria seca a plantas com maior densidade de perfilhos basais, altura, e menor número de folhas verdes por perfilho. Os resultados da análise de trilha indicaram que a interceptação luminosa é determinante na expressão do teor de matéria seca de clones de Pennisetum sp., enquanto a densidade de perfilhos basais e a altura da planta são responsáveis pela produção de matéria seca nesses clones.

Palavras-chave: análise de trilha, correlação canônica, milheto, Pennisetum sp., produção de MS, teor de MS

\section{Introduction}

Elephant grass (Pennisetum purpureum Schum.) is one of the most used forage grasses in Brazil. According to Kretschemer \& Pitman (2001), there are around 25 elephant grass cultivars and 16 hybrids with millet selected and grown throughout the world. The species germplasm is highly heterozygote and presents high variability, mostly coming from the protogyny. This fact implicates that Pennisetum sp. genotypes (elephant grass and its millets hybrids) may present distinct morphological and productive characteristics.

The study of the relationship between the morphological and productive characteristics of the plant is rather important for improvement. According to Floss (2006), the main genetic gains in cereals obtained in the last few years are 
related to the selection of plants with lower height, short and erect leaves, and thick culms.

The success of an improvement program is primordially based in the existence of genetic variability. The fast and efficient use of this variability is essential, and studying the correlations is a way to gain time and reduce efforts (Cruz, 2005).

According to Daher et al. (2004), the correlation between two variables may be phenotypic, genotypic or environmental, but, only the genotypic correlations involve an inheritable relation. Despite being highly used, the simple genotypic correlation does not allow a more detailed evaluation of the association between characters.

The canonic correlation enables the evaluation of the interrelations between two groups of characteristics determined by a larger number of characters with forage importance. On the other hand, path analysis allows partitioning the simple correlation in its direct and indirect effects, in other words, it enables the analyses if a third character is indirectly acting in the relation.

Besides knowing the way through which the characteristics are associated, the manipulation of quantitative characters requires obtaining genetic parameters, which provides subsidies to evaluate the efficiency of different improvement strategies to obtain genetic gains (Cruz \& Carneiro, 2006).

Thus, the objetive of this work was to study the association between the morphological and productive characteristics in Pennisetum sp. clones and at identifying the morphological characteristics responsible for productivity in Pennisetum sp. clones, in order to guide the selection process.

\section{Material and Methods}

The experiment was conducted in the Experimental Station of the Instituto Agronômico de Pernambuco (IPA), in Itambé, in the Dry Forest Zone in the State of Pernambuco, Brazil. The city is located in the geographic coordinates $07^{\circ} 25^{\prime} 00^{\prime \prime}$ latitude and $35^{\circ} 06^{\prime} 00^{\prime \prime}$ longitude, at $190 \mathrm{~m}$ of altitude, with average annual rainfall of $1200 \mathrm{~mm}$ and average annual temperature of $25^{\circ} \mathrm{C}(\mathrm{CPRH}$, 2003). The reference-soils for the region of Itambé-PE, according to Jacomine (2001), are classified as Red-Yellow Podzolic Tb Distrophic, with A horizon prominent of average/clay texture, semideciduous tropical forest phase and smooth-wavy land relief.

Eight Pennisetum sp. genotypes were evaluated, of which eight are elephant grass clones: five small-sized (Taiwan A-146 2.37, Taiwan A-146 2.27, Taiwan-146 2.114, Merker México MX 6.31 e Mott) and two large-sized
(Elephant B, known as Mercker, one of the first genotypes introduced in Brazil, and IRI-381). Besides the elephant grass clones, a medium-sized hybrid of elephant grass with millet (HV-241) was also evaluated. The large-sized clones and Mott are recommended cultivars, while the other clones, including the hybrid, were generated by the Program of Genetic Improvement of elephant grass from IPA/UFRPE.

The soil in the experimental area was prepared mechanically by plowing and harrowing. The genotypes were implanted in $25-\mathrm{m}^{2}$ parcels ( $5 \mathrm{~m} \times 5 \mathrm{~m}$ ), with $9 \mathrm{~m}^{2}$ ( $3 \mathrm{~m} \times 3 \mathrm{~m}$ ) of useful area, in four blocks, due to the irregularity of the terrain. The planting was made in grooves spaced by $1 \mathrm{~m}$ on June $16^{\text {th }} 2007$. Because of the planting, it was used $333 \mathrm{~g}$ of potassium chloride and 1,430 $\mathrm{g}$ of simple superphosphate, corresponding to $80 \mathrm{~kg}$ of $\mathrm{K}_{2} \mathrm{O}$ and $120 \mathrm{~kg}$ of $\mathrm{P}_{2} \mathrm{O}_{5}$ /ha, respectively, uniformly distributed in the groove for potassium and phosphate fertilization, respectively.

Four harvests were made from September 2007 to May 2008, with intervals of approximately 60 days. Because of the harvests, the following characters were evaluated: leaf area index, light interception, leaf angle, basal tillers density, green leaves number, plant height, dry matter production and dry matter content.

The leaf area index, light interception and leaf angle were estimated directly using the canopy analyzer by LI-COR, model LAI 2000. Three readings were made under the canopy by positioning the device at 25, 50 and $75 \mathrm{~cm}$ from the clump base in each reading, so the space between the rows was covered by the readings. These readings were made on three spots of the experimental parcel useful area, always at dusk.

The basal tillers density was evaluated by counting this tillers class in three areas of $0.5 \mathrm{~m}^{2}$, delimited by a wooden frame, in the experimental parcel useful area. The green leaf number was determined by randomly harvesting two tillers in each area used in the counting of the structures.

Plant height was determined by using a ruler, graduated in centimeters, in three spots of the parcel useful area and corresponding to the distance from the soil to the average curve of the last leaves in the canopy top.

Dry matter production and content were estimated by weighing the forage, considering all shoot biomass, in three areas of $0.5 \mathrm{~m}^{2}$ (the same ones used in tillage counting). Afterwards, the samples were placed in a forced air greenhouse at $55^{\circ} \mathrm{C}$ to determine DM content.

The experimental design used was a randomized block design with four replications. Data were submitted to the variance analysis, considering the mean values of the four crops. Based on the significance of the F test, the means 
of each clone were compared by the Scott-Knott test, with significance level of $5 \%$. Based on the variance components, the following genetic parameters were estimated: heritability in the broad sense or genotypic determination coefficient, genetic correlation and environmental and genetic variation coefficient.

To study the interrelations between the morphological (leaf area index, light interception, leaf angle, basal tillers density, green leaves number and plant height) and the productive characters (DM production and content), the canonic correlations between these two groups of characters were analyzed. The null hypothesis: $H_{0}: \rho_{1}=\rho_{2}=\ldots=\rho_{n}=0$, with $s=\min (p, q)$ at $1 \%$ probability for the canonic correlations was tested by the Chi-square test. All procedures conducted were described by Cruz et al. (2004). The results interpretation was made based on the structural matrix or canonic factors matrix coefficient, i.e., the correlation matrix between the original and the canonic variables, according to Abreu \& Vetter (1978).

Partition of the genetic correlations enabled the identification of the characteristics responsible for the relation, the path analysis was made separately for each of the productive characters (DM production and content). The number of variables considered for each path analysis was also dependent of weak multicollinearity occurrence, i.e., condition number lower than 100 (Cruz et al., 2004). The interpretation of the path analysis result was made pursuant to recommendations by Singh \& Chaudhary (1979).

All the statistical analyses were carried out using the software GENES (Cruz, 2006).

\section{Results and Discussion}

The clones had a significant $(\mathrm{P}<0.05)$ effect on all of the studied characters, showing the variability present in these clones group as to the productive and morphological aspects. Regarding the productive aspects, it is, therefore observed that the clones Taiwan A-146 2.37, HV-241 and Elephant B showed higher DM production than the other clones (Table 1). However, for the dry mass content character, only the clone Taiwan A-146 2.37 was superior when compared to the other clones.

Regarding the morphological characters, Taiwan A-146 2.114 and Mott showed higher leaf area indexes (LAI) than the other clones. For light interception (LI), the clones Taiwan A-146 2.114 and Mott are not superior only to HV-241. Taiwan A-146 2.37 showed the lowest leaf area index and light interception. The leaf angle was not different among the clones studied (Table 1).

Taiwan A-146 2.37 and 2.27, besides HV-241, showed higher basal tillers density than the other clones. On the other hand, Mott was the clone that showed the highest green leaf number per tillers. Regarding the height, the genotypes presented striking differences, as expected; however, HV-241 did not present differences as to the largesized Elephant B although it had been classified as a medium-sized genotype. The shorter clones were Taiwan A-146 2.114 and Mott (Table 1).

The estimates of the heritability coefficient in the broad sense $\left(\mathrm{h}^{2}\right)$ varied from medium to high and present high selection potential, with prospects to genetic advance.

Table 1 - Means and genetic parameters of the productive and morphological characters of clones of elephant-grass

\begin{tabular}{|c|c|c|c|c|c|c|c|c|}
\hline \multirow[t]{3}{*}{ Clone } & \multicolumn{2}{|c|}{ Production characteristics } & \multicolumn{5}{|c|}{ Morphological characteristics } & \multirow{3}{*}{$\begin{array}{c}\text { Plant } \\
\text { height }\end{array}$} \\
\hline & $\begin{array}{c}\text { DM } \\
\text { Production }\end{array}$ & $\begin{array}{c}\text { DM } \\
\text { Content }\end{array}$ & $\begin{array}{c}\text { Leaf area } \\
\text { index }\end{array}$ & $\begin{array}{l}\text { Light } \\
\text { interception }\end{array}$ & $\begin{array}{l}\text { Leaf } \\
\text { angle }\end{array}$ & $\begin{array}{c}\text { Basal tillers } \\
\text { density }\end{array}$ & $\begin{array}{l}\text { Number of } \\
\text { green leaves }\end{array}$ & \\
\hline & $\mathrm{kg} / \mathrm{ha}$ & $\%$ & & $\%$ & $\circ$ & Tillers/m² & & \\
\hline Taiwan A-146 2.37 & $6258.3 a$ & $33.4 \mathrm{a}$ & $1.9 \mathrm{~d}$ & $69.4 c$ & $40.8 \mathrm{a}$ & $69.6 a$ & $6.5 c$ & $109.3 c$ \\
\hline Taiwan A-146 2.27 & $4690.4 b$ & $27.0 \mathrm{~b}$ & $2.5 b$ & $76.4 \mathrm{~b}$ & $51.0 \mathrm{a}$ & $52.7 \mathrm{~b}$ & $6.9 b$ & $97.1 d$ \\
\hline Taiwan A-146 2.114 & $4952.2 b$ & $23.2 b$ & $2.8 \mathrm{a}$ & $77.9 \mathrm{a}$ & $47.6 a$ & $60.2 \mathrm{a}$ & $7.1 \mathrm{~b}$ & $91.0 \mathrm{e}$ \\
\hline Mercker MX 6.31 & $4820.8 b$ & $26.7 b$ & $2.4 \mathrm{c}$ & $75.7 b$ & $48.1 \mathrm{a}$ & $46.3 b$ & $6.4 \mathrm{c}$ & $98.6 \mathrm{~d}$ \\
\hline HV-241 & $6873.3 \mathrm{a}$ & $25.3 b$ & $2.5 b$ & $77.8 \mathrm{a}$ & $47.0 \mathrm{a}$ & $67.8 \mathrm{a}$ & $6.4 \mathrm{c}$ & $127.1 b$ \\
\hline Mott & $4465.7 \mathrm{~b}$ & $27.5 b$ & $2.8 \mathrm{a}$ & $77.6 \mathrm{a}$ & $43.1 \mathrm{a}$ & $48.3 b$ & $7.9 \mathrm{a}$ & $86.3 e$ \\
\hline Elephant B & $5756.8 \mathrm{a}$ & $28.5 b$ & $2.3 c$ & $75.2 b$ & $44.1 \mathrm{a}$ & $47.3 \mathrm{~b}$ & $6.5 c$ & $122.3 b$ \\
\hline IRI-381 & $5277.6 b$ & $26.0 \mathrm{~b}$ & $2.2 \mathrm{c}$ & $75.0 \mathrm{~b}$ & 44.3a & 41.9b & $7.1 \mathrm{~b}$ & $139.2 \mathrm{a}$ \\
\hline \multicolumn{9}{|l|}{ Genetic parameters } \\
\hline Mean & 5386.9 & 27.2 & 2.4 & 75.6 & 45.7 & 54.3 & 6.8 & 108.9 \\
\hline Environmental variation coefficient (\%) & 17.3 & 11.3 & 5.9 & 1.8 & 9.2 & 12.9 & 6.4 & 5.2 \\
\hline Genetic variation coefficient (\%) & 12.9 & 9.1 & 11.7 & 3.5 & 5.6 & 18.0 & 6.7 & 17.7 \\
\hline $\mathrm{h}^{2}$ & 69.1 & 79.6 & 93.9 & 93.4 & 58.2 & 88.6 & 81.2 & 97.7 \\
\hline $\mathrm{CV}_{\mathrm{g}} / \mathrm{CV}_{\mathrm{a}}$ ratio & 0.7 & 0.8 & 1.9 & 1.9 & 0.6 & 1.4 & 1.0 & 3.4 \\
\hline
\end{tabular}

$* h^{2}=$ heritability in the broad sense.

Means followed by the same lower case letters in the column compose a statistically homogenous group (P>0.05) by Scott-Knott test. 
Nevertheless, leaf angle and DM production presented the lowest $\mathrm{h}^{2}$ values (58.2 and 69.1\%, respectively), indicating higher environmental influence in the expression of these characteristics (Table 1).

Lower $\mathrm{h}^{2}$ estimates were obtained by Silva (2006) for DM production (39\%) and leaf blades DM content (54\%). Daher et al. (2004) found $h^{2}$ values that varied from $33 \%$, for DM production, to $84 \%$ for plant height. Nevertheless, $\mathrm{h}^{2}$ estimates are peculiar to the evaluated genotypes set and to the determined environmental condition (Acquaah, 2007).

The genetic variation coefficients (GVC, Table 1), which express the existent genetic variation quantity in percentage from the overall mean, presented higher values for basal tillers density (18\%), plant height (17.7\%), LAI (11.7\%) and DM production (12.9\%). Bueno et al. (1001) emphasized that, in order to make the selection of genetically superior individuals efficient, there must be enough genotypic variation in the original population.

Most of the characteristics showed GVC/EVC ratios superior to the unit (Table 1), especially plant height (3.3). These results reveal that clones that are superior in these characteristics can be obtained by using simple selection methods. According to Falconer (1987), satisfactory selection gains are possible when the variation index is superior to the unit, which demonstrates that most of the variability expressed for a determined characteristic has genetic origin.

Hybridizing elephant grass, especially with millet, is currently the main genetic improvement tool used to increase the genetic basis and to best use the heterosis. Therefore, elephant grass improvement can follow two basic lines, the first by obtaining clones, which has been more used, and the second through population. Because it is a species with high levels of heterozygous, elephant grass hybridization provides progenies with great variability. Genetic variability is the base of all selection and, as to elephant grass, selected genotypes with desired characteristics may be easily kept by vegetal propagation, facilitating the use of hybrid heterosis (Pereira et al., 2001).
Regarding the genotypic correlation, it was observed that the DM content presented high and significant correlation with the leaf area index, light interception and leaf angle; however, the correlation was negative for the first two characteristics correlation. The DM production, on the other hand, presented significant and positive correlation with the number of basal tillers and plant height, and negative, but significant, correlation with the leaf area index and green leaf number. The correlation between DM content and DM production was not significant, indicating that there was no relation between these characteristics (Table 2).

The canonic correlations were significant at $1 \%$ probability by the Chi-square test, showing that the considered groups are not independent. The canonic correlation of the first canonic pair and also the second pair were raised (Table 3 ).

Based on the coefficient analysis of the canonic factors matrix, i.e., the correlation matrix between the original and canonic variables, it is possible to assume that the first pair of canonic factors, with correlations of 0.9999 , relates plants with higher DM content to plants with lower leaf area index, light interception and leaf angle. The second pair of canonic factors, with correlations of 0.9999 , relates plants with higher DM content to plants with higher basal tillers density and height, and lower green leaves number per tiller.

In a certain way, the results of the canonic correlation confirmed the simple genotypic correlations; however, they made possible a more rational grouping of the associations. Cruz et al. (2004) commented that the great advantage of this technique is the possibility to aid the breeder in studies that involve more than one dependent variable, thus directing the efforts to characters that are highly heritable, easy to measure and less complex than DM production.

Partitioning the genotypic correlation between DM content and leaf area index considers that, although the correlation was negative and strong, the direct effect of the leaf area index on the DM content was weak, showing that the indirect effects counted more on the DM content

Table 2 - Genotypic correlation coefficients between the productive and morphological characteristics in eight clones of elephant grass

\begin{tabular}{|c|c|c|c|c|c|c|c|}
\hline Characters $^{+}$ & $\begin{array}{c}\text { DM } \\
\text { content }\end{array}$ & $\begin{array}{c}\text { Leaf area } \\
\text { index }\end{array}$ & $\begin{array}{c}\text { Light } \\
\text { interception }\end{array}$ & $\begin{array}{l}\text { Leaf } \\
\text { area }\end{array}$ & $\begin{array}{c}\text { Basal tillers } \\
\text { number }\end{array}$ & $\begin{array}{l}\text { Number of } \\
\text { green leaves }\end{array}$ & $\begin{array}{l}\text { Plant } \\
\text { height }\end{array}$ \\
\hline DM production & 0.2970 & $-0.7188 *$ & -0.5040 & 0.5942 & $0.7265 *$ & $-0.8250 *$ & $0.7707^{*}$ \\
\hline DM content & & $-0.9043 *$ & $-0.9999 *$ & $0.9999 *$ & 0.3669 & -0.2373 & 0.0731 \\
\hline Leaf area index & & & $0.9076^{*}$ & -0.6223 & -0.1984 & 0.6679 & -0.6271 \\
\hline Light interception & & & & $-0.7643 *$ & -0.3251 & 0.4453 & -0.2432 \\
\hline Leaf angle & & & & & 0.1901 & 0.2405 & 0.2938 \\
\hline Basal tillers number & & & & & & -0.4628 & -0.0822 \\
\hline Number of live plants & & & & & & & -0.4862 \\
\hline
\end{tabular}

*Significant by the $\mathrm{t}$ test $(\mathrm{P}<0.05)$. 
Table 3 - Matrix coefficients of the canonic factors between groups 1 and 2 in clones of elephant grass

\begin{tabular}{|c|c|c|c|}
\hline \multirow[t]{2}{*}{ Group } & \multirow[t]{2}{*}{ Characters* } & \multicolumn{2}{|c|}{ Canonic factor } \\
\hline & & $1^{\mathrm{st}}$ & $2^{\text {nd }}$ \\
\hline 1 - Productive characters & DM production & 0.2415 & 0.9704 \\
\hline \multirow[t]{4}{*}{2 - Morphological characters } & Leaf area index & -0.7695 & -0.5027 \\
\hline & Light interception & -0.9601 & -0.2380 \\
\hline & Leaf angle & -0.9024 & -0.3431 \\
\hline & Plant height & 0.0245 & 0.7571 \\
\hline Canonic correlation* & & $0.9999 * *$ & $0.9999 * *$ \\
\hline$\chi^{2}$ & & 69 & 34 \\
\hline Freedom degree & & 12 & 5 \\
\hline
\end{tabular}

* Correlation between the first and the second canonic pair.

**Highly significant $(\mathrm{P}<0.01)$ by the Chi-square test.

expression. Such effect is evidenced specially for the light interception, which presented indirect effect in the same magnitude and sign than the genotypic correlation between DM content and leaf area index (Table 4).

The genotypic correlation between DM content and light interception, as well as the direct effect, was strong and negative, indicating that this correlation explains the true association between these characters.

A positive and strong genotypic correlation with the DM content was observed as it was for leaf angle, but the direct effect of the leaf angle on this character is weak and negative, indicating that the indirect effects were more important on the DM content expression as it was observed for the leaf area index. Regarding the indirect effects, it is observed that the light interception was, once more, decisive in the DM content expression for its positive and strong effect.

Table 4 - Partitioning of the genotypic correlations of grass elephant characters under cut in direct and indirect effects on DM content by path analysis

\begin{tabular}{lc}
\hline Characteristic & Effect \\
\hline Leaf area index & \\
Direct effect on DM content & 0.3908 \\
Indirect effect via light interception & -0.9999 \\
Indirect effect via leaf angle & -0.2591 \\
Total & $-0.9043^{+}$ \\
Light interception & -0.9999 \\
Direct effect on DM content & 0.3547 \\
Indirect effect via leaf area index & -0.3183 \\
Indirect effect via leaf angle & $-0.9999^{+}$ \\
Total & \\
Leaf angle & -0.4164 \\
Direct effect on DM content & 0.2432 \\
Indirect effect via leaf area index & -0.8724 \\
Indirect effect via light interception & $-0.9999^{+}$ \\
Total & 1.0000 \\
Determination coefficient & 0.0000 \\
\hline Residual effect
\end{tabular}

${ }^{+}$Significant by the $\mathrm{t}$ test $(\mathrm{P}<0.05)$.
The selection to increase DM content of Pennisetum sp. can be rather useful to this grass ensilage process, once the DM content in the recommended cutting age (between 50 and 70 days of growth) is between 80 and $85 \%$ below the recommended (Lavezzo et al., 1989; Carvalho et al., 2007). Moreover, Silva et al. (2008b) observed that there was variability for the character DM content in different Pennisetum sp. progenies, obtained from intraspecific and interspecific crosses with millet, and by selfing. In this work, around $20 \%$ of the interspecific hybrids presented DM content between 30 and 33\%; nevertheless, other characters need to be considered, such as soluble carbohydrates content, buffer power and overall silage quality.

In this work, the decisive role of the lowest light interception on the expression of DM content in Pennisetum sp. clones, both directly and indirectly, via leaf area index and leaf angle, was evident. Warren Wilson (1963) demonstrated that more erect leaves use light more efficiently and that, in the same vertical projection area, they may present higher liquid assimilation than more horizontal leaves. This can explain the fact that Pennisetum sp. clones, even with the lowest interception and leaf area index, presented higher DM content. It is possible that higher efficiency of light use occurred due to leaves disposed more erectly.

The leaf angle determination is important in several types of studies. Stress and environmental factors induce changes in the leaf angle. These changes are important because leaf angle influences light absorption in the canopy and, consequently, photosynthesis (Deckmyn et al., 2000).

Regarding the partitioning of the characteristics related to the second canonic pair, the basal tillers density and plant height directly influenced DM production since their effects were in the same magnitude and signal as the genotypic correlations. Green leaves number/tiller had strong and negative genotypic correlation with DM 
production, however, its direct effect was negligible, showing that the basal tillers density and plant height had higher influence in this relation (Table 5).

Daher et al. (2004) also observed that elephant grass plant height influences DM production especially in cases of clones with high tillering capacity. However, even though Silva et al. (2008a) found that the height affects DM production, they observed that this relation was indirectly influenced by the number of leaves per tillers, and not by basal tillers density. The authors explained that the studied clones suffered from water stress, which caused an increase of tillers population density in some cuts, though without growth, resulting in lighter tillers, with a smaller number of phytomers.

During the development of the grass, the number of green leaves per tiller increases while the senescence and leaf death processes are not initiated (Gomide \& Gomide, 2000), after which, the number of green leaves per tiller tends to be constant for a particular genotype (Gomide et al., 2006).

Negative association between green leaves number and DM production can be better explained by basal tillers density. Although the number of green leaves per tiller is constant for a particular genotype, the senescence and leaf death processes are quite influenced by the environment. In a high basal tilling situation, the shadowing can affect the number of green leaves due to higher senescence. Nevertheless, despite the low green leaves number, the DM

Table 5 - Partitioning of the genotypic correlations of elephant grass characters under cut in direct and indirect effects on DM production by the path analysis

\begin{tabular}{lc}
\hline Characteristic & Effect \\
\hline Basal tillers density & \\
Direct effect on DM production & 0.7450 \\
Indirect effect via green leaves & 0.0459 \\
number/basal tiller number & -0.0644 \\
Indirect effect via plant height & $0.7265^{+}$ \\
Total & \\
Green leaves number/basal tiller number & -0.0992 \\
Direct effect on DM production & -0.3448 \\
Indirect effect via basal tillers density & -0.3810 \\
Indirect effect via plant height & $-0.8250^{+}$ \\
Total & \\
Plant height & 0.7837 \\
Direct effect on DM production & -0.0612 \\
Indirect effect via basal tillers density & 0.0482 \\
Indirect effect via green leaves & \\
number/basal tiller number & $0.7707^{+}$ \\
Total & 1.0000 \\
Determination coefficient & 0.0000 \\
Residual effect
\end{tabular}

${ }^{+}$Significant by $t$ test $(\mathrm{P}<0.05)$. production was possibly compensated by the higher basal tillers number.

The results of this work show the importance of studies with canonic correlation and path analysis to understand the relations between morphological and productive characteristics. In Pennisetum sp. genetic improvement programs, the relation between the productive and morphological characteristics must be considered, inasmuch as the change in a particular characteristic may lead to changes in another, causing implications on the selection of Pennisetum sp. genotypes.

\section{Conclusions}

When the selection is directed to increasing dry matter content, elephant grass clones with low leaf area, low light interception and with the lowest leaf angle must be selected. If the objective is a higher dry mass production, higher plants with lower green leaves number per tiller and higher basal tillers number are suggested. Light interception is a determinant in DM content expression of Pennisetum sp. clones, whilst the basal tillers density and plant height are responsible for DM production in the evaluated clones.

\section{Acknowledgements}

To CNPq, for granting the research fund to the authors Mário de Andrade Lira, Mércia Virginia Ferreira dos Santos and José Carlos Batista Dubeux Junior.

\section{References}

ABREU, M.A.; VETTER, D.A. Análise de relação entre conjuntos de variáveis na matriz geográfica: correlação canônica. In: FAISSOL, S. (Ed.) Tendências atuais na geografia urbano/ regional: teorização e quantificação. Rio de Janeiro: IBGE, 1978. p.133-144.

ACQUAAH, G. Principles of plant genetics and breeding. Oxford: Blackwell Publishing, 2007. 569p.

BUENO, L.C.; MENDES, A.N.G.; CARVALHO, S.P. Melhoramento genético de plantas: princípios e procedimentos. Lavras: UFLA, 2001. 282p.

CARVALHO, G.G.P.; GARCIA, R.; PIRES, A.J.V. et al. Valor nutritivo e características fermentativas de silagens de capimelefante com adição de casca de café. Revista Brasileira de Zootecnia, v.36, n.6, p.1875-1881, 2007.

COMPANHIA PERNAMBUCANA DO MEIO AMBIENTE - CPRH Diagnóstico socioambiental do litoral norte de Pernambuco. Recife: 2003. 214p.

CRUZ, C.D. Princípios de genética quantitativa. Viçosa, MG: UFV, 2005. 349p.

CRUZ, C.D. Programa Genes: análise multivariada e simulação. Viçosa, MG: UFV, 2006. 175p. 
CRUZ, C.D.; CARNEIRO, P.C.S. Modelos biométricos aplicados ao melhoramento genético. 2.ed. Viçosa, MG: UFV, v.2, 2006. $585 p$.

CRUZ, C.D.; REgAZZI, A.J.; CARneiro, P.C.S. Modelos biométricos aplicados ao melhoramento genético. Viçosa, MG: UFV, 2004. v.1. 480p.

DAHER, R.F.; PEREIRA, A.V.; PEREIRA, M.G. et al. Análise de trilha de caracteres forrageiros do capim-elefante (Pennisetum purpureum Schum.). Ciência Rural, v.34, n.5, p.1531-1535, 2004.

DECKMYN, G.; NIJS, I.; CEULEMANS, R. A simple method to determine leaf angles of grass species. Journal Experimental of Botany, v.51, n.349, p.1467-1470. 2000.

FALCONER, D.S. Introdução à genética quantitativa. Viçosa, MG: UFV, 1987. 279p.

FLOSS, E.L. Fisiologia de plantas cultivadas: o estudo do que está por trás do se vê. 3.ed. ampl.e atual. Passo Fundo: Universidade de Passo Fundo, 2006. 751p.

GOMIDE, C.A.M.; GOMIDE, J.A. Morfogênese de cultivares de Panicum maximum Jacq. Revista Brasileira de Zootecnia, v.29, n.3, p.341-348, 2000.

GOMIDE, C.A.M.; GOMIDE, J.A.; PACIULLO, D.S.C. Morfogênese como ferramenta para o manejo de pastagens. Revista Brasileira de Zootecnia, v.35, supl. esp., p.554-579, 2006.

JACOMINE, P.K.T. Evolução do conhecimento sobre solos coesos no Brasil. In: WORKSHOP COESÃO EM SOLOS DOS TABUlEIROS COSTEIROS, 2001, Aracaju. Anais... Aracaju: Embrapa Tabuleiros Costeiros, 2001. p.19-46.

KRETSCHEMER, E.A.; PITMAN, W.D. Germplasm resources of tropical forage grasses. In: SOTOMAYOR-RIOS, A.;
PITMAN, W.D. Tropical forage plant: development and use. Gainesville: CRC Press LLC, 2001. p.27-40.

LAVEZZO, W.; LAVEZZO, O.E.N.M.; BONASSI, I.A. Valor nutritivo de silagens de capim-elefante (Pennisetum purpureum, Schum.), cultivares Mineiro e Vruckona, submetidos ao emurchecimento e diferentes aditivos inibidores da fermentação. Revista da Faculdade de Medicina Veterinária e Zootecnia, v.26, n.2, p.249-258, 1989.

PEREIRA, A.V.; VALLE, C.B.; FERREIRA, R.P. et al. Melhoramento de forrageiras tropicais. In: NASS, L.L.; VALOIS, A.C.C.; MELO, I.S. (Eds.). Recursos genéticos e melhoramento de plantas. Rondonópolis: Fundação MT, 2001. p.449-601.

SILVA, M.A.; LIRA, M.A.; SANTOS, M.V.F. et al. Análise de trilha em caracteres produtivos de Pennisetum sob corte em Itambé, Pernambuco. Revista Brasileira de Zootecnia, v.37, n.7, p.1185-1191, 2008a.

SILVA, M.C.; SANTOS, M.V.F.; LIRA, M.A. et al. Ensaios preliminares sobre autofecundação e cruzamentos no melhoramento do capim-elefante. Revista Brasileira de Zootecnia, v.37, n.3, p.401-410, 2008b.

SILVA, S.H.B. Avaliação de clones de Pennisetum purpureum Schum. de porte baixo, na Zona da Mata Seca de Pernambuco. Recife: UFRPE, 2006. 65f. Dissertação (Mestrado em Zootecnia) - Universidade Federal Rural de Pernambuco, Recife.

SINGH, R.K.; CHAUDHARY, B.D. Biometrical methods in quantitative genetic analysis. Ludhiana: Kalyani Publishers, 1979. p.223.

WARREN WILSON, J. Estimation of foliage denseness and foliage angle by inclined point quadrats. Australian Journal of Botany, v.11, n.2, p.95-105, 1963. 